\title{
Nutritional status and food consumption of pregnant women in a development area of Israel
}

\author{
By K. GUGGENHEIM and JUDITH ILAN \\ Laboratory of Nutrition, Department of Biochemistry, Hebrew University-Hadassah \\ Medical School, ferusalem \\ AND T. VAGO AND G. MUNDEL \\ Departments of Obstetrics and Gynaecology and Pediatrics C, Government Hospital, \\ Zreefin, Israel
}

(Received 25 November 1959-Revised 21 January 1960)

The purpose of the survey was to gain information on food habits and conditions and status of nutrition of pregnant women in one of Israel's development areas. These areas, the most important of which is the southern part of the country, called the Negev, with its capital Be'er-Sheba, are underpopulated and both economically and agriculturally underdeveloped; there new immigrants are employed in road building, afforestation and other public works projects. On arrival they live in camps in small tin and wooden huts. Later, they settle in villages or small towns which they erect with governmental help. This system strives for a solution of two difficult problems which face the State of Israel: economic development of the country and absorption of the masses of immigrants. Many of the newcomers, originating in underdeveloped Near and Middle Eastern countries, are unskilled or semi-skilled labourers and have lived under backward cultural and health conditions. It is clear that serious social and public-health problems arise in this situation.

Since we were not able to carry out a country-wide survey on representative groups of all parts of the population of Is rael, a nutritionally vulnerable group was chosen: immigrant pregnant women living in a development area. Signs of malnutrition were thought to be more widespread among this sample of the total population than in the rest, and if signs of a specific deficiency were found to be absent, it could safely be concluded that malnutrition is not a major public-health problem to the country.

\section{METHODS}

The survey was made between February 1958 and March 1959. The sample studied comprised 164 pregnant women who had arrived in Israel after 1954 and were living in Be'er-Sheba and four other small towns of the Negev. One-third was in the second trimester of pregnancy and two-thirds in the third; $19 \%$ were under $2 \mathrm{r}$ years old, $60 \%$ between 21 and 30 , and $21 \%$ over 30 years; $21 \%$ were primigravidae, $50 \%$ were in their second to fifth pregnancy, $24 \%$ in their sixth to ninth, and $5 \%$ in their tenth to fifteenth. Thus, most of the women were relatively young and had had already many preganancies. 
The study comprised a clinical, biochemical and dietetic examination. The women were invited to the Mother and Child Health Centre and were asked to bring with them a sample of their morning urine. At the Centre they underwent a careful nutritional and clinical examination. Blood was taken from a finger for determination of haemoglobin and from a vein for determination of serum proteins. Haemoglobin was determined by the cyanmethaemoglobin method (Crosby, Munn \& Furth, 1954) and total protein in serum by the method of Weichselbaum (1946) as modified by Gornall, Bardawill \& David (1949). Albumin and globulin were separated by Kingsley's (1940) method, and albumin was determined by the biuret method, globulin being calculated by difference. Among the vitamins only riboflavin was studied, since this vitamin is most abundant in animal foods, consumption of which is limited in lower social groups. Riboflavin in urine was determined fluorimetrically (Interdepartmental Committee on Nutrition for National Defense, 1957) and creatinine by the method of Taussky (1954).

The dietary examination took place in a Mother and Child Health Centre or in the home of the subject. The low educational level of most of the women limited the choice of method. Since recording of the diet or weighing of the foods consumed by the women themselves was impossible, Public Health nurses interviewed the women about all foods eaten; their quantities in ordinary household measures were entered on forms for each meal and each snack. Records were made for 3 days, one being a Sabbath. Inclusion of a Sabbath proved to be necessary, since food consumption on this day was always much larger than on work-days. Records of consumption were obtained from most of the women who were examined clinically and biochemically, but only roo appeared to be reliable, gross discrepancies being found in the other records, which were discarded. Only the former are, therefore, included in the present report.

As in the total sample, one-third of this smaller sample was in the second trimester of pregnancy and two-thirds in the third; $2 \mathrm{x} \%$ were under $2 \mathrm{r}$ years old, $55 \%$ between 21 and 30 and $24 \%$ over 30 years; $23 \%$ were primigravidae, $45 \%$ in their second to fifth pregnancy, $29 \%$ in their sixth to ninth and $3 \%$ in their tenth to fifteenth. The composition of the sample in the dietary survey does not appear to differ much from that of the total sample.

The detailed entries on the record forms were tabulated on calculation sheets in which food items and quantities were listed in a standardized manner. Nutritive values were calculated throughout from a specially prepared table which was in general derived from the tables of Albritton (1954) and of Watt \& Merrill (I950). The vitamin and mineral contents of vegetables and fruits were calculated from the values of Halevy, Koth \& Guggenheim (1957), which are based on analyses of locally grown products. Representative samples of some unusual foods, for which no values are given in the tables, were analysed in our laboratory. Corrections were made for vitamin losses in cooking as described by Moore, Purdy, Gibbens, Hollinger \& Goldsmith (1947).

Each woman's mean daily consumption of nutrients was calculated by multiplying the intake on 2 work-days by 3 , adding the intake on the Sabbath and dividing the total by 7 . Mean daily consumption was compared with the allowances recommended by the British Medical Association: Committee on Nutrition (1950). 


\section{RESULTS}

Clinical examination. The incidence of pathological findings that may be attributed to nutritional deficiency is shown in Table $\mathbf{I}$. Many women displayed a combination of two or more signs. But a combination of clinical indicators of a specific vitamin deficiency as postulated by Joliffe, Goodhart, Archer, Lopez \& Diaz (I958) was very rare. One woman exhibited both angular stomatitis and dyssebacia, which suggests ariboflavinosis. In another the triad of gross conjunctival spots, xerosis and follicular hyperkeratosis was found, indicating vitamin A deficiency.

\begin{tabular}{|c|c|c|c|}
\hline Hair: & & Lips: & \\
\hline Sparse & $2 \cdot 4$ & Cheilosis & $I \cdot 2$ \\
\hline Depigmented & $1 \cdot 2$ & Angular stomatitis & $6 \cdot 0$ \\
\hline Skin: & & Tongue: & \\
\hline Xerosis & $17 \cdot 2$ & Hypertrophic papillae & $30 \cdot 0$ \\
\hline Mild follicular changes & $11 \cdot 6$ & Atrophic papillae & $26 \cdot 3$ \\
\hline Follicular hyperkeratosis & 14.7 & Gums: & \\
\hline Perifolliculitis & $7 \cdot 3$ & Hyperaemia & 6.7 \\
\hline Face: & & Swollen & 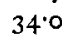 \\
\hline Dyssebacia & $2 \cdot 4$ & Interdental papillae hypertrophic & $37 \cdot 2$ \\
\hline Eyes: & & Interdental papillae atrophic & $6 \cdot 7$ \\
\hline Gross conjunctival spots & II 6 & & \\
\hline Corneal vascularization & 6.7 & & \\
\hline
\end{tabular}

Biochemical findings. The values are given with their standard deviations. The mean haemoglobin value was $\mathrm{II} \cdot 3 \pm 1 \cdot 17 \mathrm{~g} / 100 \mathrm{ml}$. Anaemia (haemoglobin content less than $10.0 \mathrm{~g} / 100 \mathrm{ml}$ ) was observed in $12 \%$ of the women. Mean serum total-protein, albumin and globulin values were $6.3 \pm \mathrm{r} \cdot 54,3.9 \pm 0.37$ and $2.4 \pm 0.46 \mathrm{~g} / 100 \mathrm{ml}$, respectively. Low values for serum proteins (below $5.5 \mathrm{~g}$ ), albumin (below $3.5 \mathrm{~g}$ ) and globulin (below $2 \cdot 0 \mathrm{~g}$ ) were found in 3,8 and $14 \%$, respectively, of the subjects. The mean excretion of riboflavin was $24.6 \pm 14.5 \mu \mathrm{g} / 100 \mathrm{ml}$ urine or $0.30 \pm 0.13 \mathrm{mg} / \mathrm{g}$ creatinine. In $53 \%$ of the women the excretion of riboflavin was more than $0.27 \mathrm{mg} / \mathrm{g}$ creatinine, which is considered as 'high' (Interdepartmental Committee on Nutrition for National Defense, 1957$)$; in $47 \%$ it was 'acceptable' $(0.08-0.27 \mathrm{mg})$; in none was a 'low' excretion ( $<0.08 \mathrm{mg}$ ) found.

Dietary survey. Values for daily food consumption (Table 2) reveal quite a different pattern for work-days than for the Sabbath. Whereas the work-day intake of cereals, fruits and vegetables, fats and oils, and pulses did not differ much from that on the Sabbath, consumption of meat, poultry, fish, eggs, nuts and seeds, sugar and sweets, and of beer and wine was much greater on the Sabbath. In contrast, consumption of milk and milk products was less on the Sabbath. The festive meals on the Sabbath, unlike the very modest everyday meals, provided in most families of the women investigated poultry, fish, meat and eggs. Since the Jewish dietary law prohibits consumption of milk and milk products together with meat, the intake of this food group was less on the Sabbath even than the very low consumption on work-days. The cracking of peanuts and sunflower seeds and the eating of many kinds of sweets 
constitutes a widespread pastime on the Sabbath, even in the poorer classes of the population, and especially among people of Near and Middle Eastern origin.

The different food habits were reflected in large differences in the nutritive value of the diets (Table 3). As the result of the lower consumption of milk and milk products the Sabbath menu provided larger amounts of all nutrients studied except calcium and vitamin $\mathrm{A}$. The greatest differences were in animal protein and nicotinic acid.

Table 2. Mean daily food consumption ( $g$, as purchased) of 100 pregnant women in Israel

\begin{tabular}{|c|c|c|}
\hline Foodstuff & Work-day & Sabbath \\
\hline $\begin{array}{l}\text { Cereals: } \\
\text { Bread } \\
\text { Other wheat products } \\
\text { Rice }\end{array}$ & $\begin{array}{r}231 \\
76 \\
13\end{array}$ & $\begin{array}{r}200 \\
102 \\
21\end{array}$ \\
\hline $\begin{array}{l}\text { Total } \\
\text { Fruits and vegetables: } \\
\text { Potatoes } \\
\text { Tomatoes } \\
\text { Citrus fruits and juices } \\
\text { Others }\end{array}$ & $\begin{array}{r}64 \\
72 \\
176 \\
187\end{array}$ & $\begin{array}{r}75 \\
53 \\
218 \\
166\end{array}$ \\
\hline $\begin{array}{l}\quad \text { Total } \\
\text { Pulses } \\
\text { Nuts and seeds } \\
\text { Sugar and sweets } \\
\text { Fats and oils }\end{array}$ & $\begin{array}{r}499 \\
27 \\
3 \\
36 \\
41\end{array}$ & $\begin{array}{r}5 \times 2 \\
25 \\
54 \\
49 \\
39\end{array}$ \\
\hline $\begin{array}{l}\text { Meat, poultry, fish and eg } \\
\text { Meat } \\
\text { Poultry } \\
\text { Fish } \\
\text { Eggs }\end{array}$ & $\begin{array}{l}23 \\
32 \\
16 \\
44\end{array}$ & $\begin{array}{r}36 \\
110 \\
51 \\
57\end{array}$ \\
\hline Total & I I 5 & 254 \\
\hline $\begin{array}{l}\text { Milk and milk products: } \\
\text { Milk } \\
\text { Cream and cheese }\end{array}$ & $\begin{array}{r}189 \\
21\end{array}$ & $\begin{array}{r}113 \\
9\end{array}$ \\
\hline Total & 210 & 124 \\
\hline Beer and wine & 41 & 103 \\
\hline
\end{tabular}

The relatively high amounts of calcium and riboflavin contributed by cereals are partly the result of enrichment of flour which is controlled by the Government. At present all flour milled in this country is fortified with $3 \circ \mathrm{g}$ heat-processed soya-bean meal, $2.5 \mathrm{~g}$ calcium carbonate and $2.5 \mathrm{mg}$ ribollavin per $\mathrm{kg}$. Fortification of flour contributed $0.45 \mathrm{mg}$ riboflavin and $269 \mathrm{mg}$ calcium to the mean daily diet of the women studied, or 37 and $31 \%$, respectively, of total consumption.

Values for the mean daily consumption of nutrients are presented in Table 3 and for the percentage of diets attaining different levels of the recommended allowances in Table 4. It can be seen that the mean consumption of most nutrients, especially that of calcium and of vitamin $\mathrm{A}$, but not that of thiamine or ascorbic acid, was below 
the recommended allowances of the British Medical Association. The diet of over half the women provided $75 \%$ or more of the recommended amounts of calories, thiamine, riboflavin, nicotinic acid and ascorbic acid. The percentage of the women with an intake less than $50 \%$ of the recommended allowance was for calcium 60 , for vitamin A 35 , for iron 14 and for protein 12.

Table 3. Mean daily consumption of nutrients by 100 pregnant women in Israel

\begin{tabular}{|c|c|c|c|c|c|c|c|c|c|}
\hline Foodstuff & $\begin{array}{c}\text { Calories } \\
\text { (kcal) }\end{array}$ & $\begin{array}{l}\text { Protein } \\
\text { (g) }\end{array}$ & $\begin{array}{l}\text { Calcium } \\
\text { (mg) }\end{array}$ & $\begin{array}{l}\text { Iron } \\
\text { (mg) }\end{array}$ & $\begin{array}{c}\text { Vitamin } \\
\text { A } \\
\text { (i.u.) }\end{array}$ & $\begin{array}{l}\text { Thiamine } \\
\text { (mg) }\end{array}$ & $\begin{array}{l}\text { Ribo- } \\
\text { flavin } \\
\text { (mg) }\end{array}$ & $\begin{array}{c}\text { Nico- } \\
\text { tinic } \\
\text { acid } \\
(\mathbf{m g})\end{array}$ & $\begin{array}{c}\text { As- } \\
\text { corbic } \\
\text { acid } \\
(\mathrm{mg})\end{array}$ \\
\hline \multicolumn{10}{|c|}{ Work-day } \\
\hline Cereals & 889 & $29 \cdot 4$ & 272 & $3 \cdot 57$ & - & 0.55 & 0.56 & $3 \cdot 5$ & - \\
\hline Fruits and vegetables & 167 & $4 \cdot 6$ & 104 & 3.19 & 2497 & 0.27 & O.I I & $I \cdot 7$ & 87 \\
\hline Pulses & 94 & $5 \cdot 9$ & 27 & $x \cdot 62$ & $8 \mathrm{I}$ & O.II & 0.05 & 0.5 & - \\
\hline Nuts and seeds & 17 & 0.8 & 2 & 0.03 & 一 & 0.02 & - & 0.3 & - \\
\hline Sugar and sweets & 140 & 0.2 & 6 & 0.07 & $\mathbf{I}$ & O.OI & - & - & 一 \\
\hline Fats and oils & 340 & - & - & - & 480 & - & - & - & - \\
\hline $\begin{array}{l}\text { Meat, poultry, fish and } \\
\text { eggs }\end{array}$ & 170 & $17 \cdot 6$ & $3 \mathbf{I}$ & $2 \cdot 09$ & 464 & 0.07 & 0.17 & $3 \cdot 2$ & 一 \\
\hline Milk and milk products & 149 & $8 \cdot 5$ & 265 & 0.24 & 282 & 0.08 & $0 \cdot 33$ & 0.2 & 2 \\
\hline Beer and wine & 20 & - & 2 & - & - & $\longrightarrow$ & o.or & $0 \cdot 1$ & - \\
\hline Total & I 986 & $67 \cdot 0^{*}$ & 709 & 10.61 & $3^{805}$ & $I \cdot I I$ & $I \cdot 23$ & $9 \cdot 5$ & 89 \\
\hline \multicolumn{10}{|c|}{ Sabbath } \\
\hline Cereals & 909 & $29 \cdot 7$ & 279 & $3 \cdot 39$ & - & 0.54 & 0.57 & $3 \cdot 5$ & - \\
\hline Fruits and vegetables & 200 & $4^{\circ} 9$ & 112 & $3 \cdot 50$ & 2289 & 0.30 & 0.12 & $I \cdot 7$ & 96 \\
\hline Pulses & 87 & $5 \cdot 5$ & 25 & $1 \cdot 50$ & 75 & 0.10 & 0.05 & 0.5 & $\longrightarrow$ \\
\hline Nuts and seeds & $33^{8}$ & $13 \cdot 4$ & 24 & 0.68 & - & 0.31 & 0.07 & $4 \cdot 9$ & 一 \\
\hline Sugar and sweets & I9I & 0.3 & 7 & 0.13 & 4 & 0.01 & $0.0 \mathrm{I}$ & - & 一 \\
\hline Fats and oils & 329 & - & $\cdots$ & - & 360 & - & 一 & - & 一 \\
\hline $\begin{array}{l}\text { Meat, poultry, fish and } \\
\text { eggs }\end{array}$ & 348 & $38 \cdot I$ & 53 & $3 \cdot 92$ & 634 & 0.13 & 0.32 & $8 \cdot 2$ & - \\
\hline Milk and milk products & 81 & $4 \cdot 8$ & 147 & 0.13 & $\mathrm{r} 45$ & 0.05 & 0.19 & $0 \cdot 1$ & $\mathbf{I}$ \\
\hline Beer and wine & 50 & - & 4 & - & - & - & 0.03 & 0.2 & $\longrightarrow$ \\
\hline Total & 2533 & $96 \cdot 7 \dagger$ & $65 I$ & 13.25 & 3507 & $I \cdot 44$ & $x \cdot 36$ & I $9^{\circ}$ I & 97 \\
\hline \multicolumn{10}{|c|}{ Daily consumption during week $\ddagger$} \\
\hline Total & 2064 & $7 x \cdot 3$ & 701 & 10.99 & 3763 & $I \cdot I 7$ & $I \cdot 23$ & 10.9 & 90 \\
\hline
\end{tabular}

Table 4. Dietary survey of 100 pregnant women in Israel: numbers whose intakes of nutrients attained stated proportions of the allowances recommended by the British Medical Association: Committee on Nutrition (1950) for women in the second half of pregnancy

\begin{tabular}{|c|c|c|c|c|c|c|c|c|c|}
\hline \multirow{2}{*}{$\begin{array}{c}\text { Percentage } \\
\text { of } \\
\text { allowance }\end{array}$} & \multirow[b]{2}{*}{ Calories } & \multirow{3}{*}{$\begin{array}{c}\text { Protein } \\
6\end{array}$} & \multirow{3}{*}{$\underset{\circ}{\text { Calcium }}$} & \multirow{3}{*}{$\begin{array}{c}\text { Iron } \\
\text { II }\end{array}$} & \multirow[b]{2}{*}{$\begin{array}{c}\text { Vitamin } \\
\text { A }\end{array}$} & \multirow[b]{2}{*}{ Thiamine } & \multirow[b]{2}{*}{$\begin{array}{l}\text { Ribo- } \\
\text { flavin }\end{array}$} & \multirow[b]{2}{*}{$\begin{array}{l}\text { Nicotinic } \\
\text { acid }\end{array}$} & \multirow{3}{*}{$\begin{array}{c}\text { Ascorbic } \\
\text { acid } \\
84\end{array}$} \\
\hline & & & & & & & & & \\
\hline 100 or more & 5 & & & & I I & 53 & 16 & 37 & \\
\hline $75-99$ & 46 & 42 & 6 & 37 & 30 & 33 & 38 & 33 & 7 \\
\hline $50-74$ & 45 & 40 & 34 & 38 & 24 & I3 & 39 & 25 & 5 \\
\hline$<50$ & 4 & 12 & 60 & 14 & 35 & 2 & 7 & 5 & 4 \\
\hline
\end{tabular}




\section{DISCUSSION}

Vitamin deficiency does not appear to be widespread among the population sample studied. One subject out of 164 exhibited signs of vitamin A deficiency and another signs suggestive of riboflavin deficiency, which is a very small proportion in view of the selection of the subjects.

The mean haemoglobin content was II.3 g/I00 $\mathrm{ml}$, with $12 \%$ of the values below $10.0 \mathrm{~g}$, which is considered as diagnostic of anaemia in pregnancy (WHO, I958). A similar percentage (II) was recently reported by Izak, Rachmilewitz, Stein, Berkovici, Sadovsky, Aronovitch \& Grossowicz (1957) in a sample of 2500 pregnant women in Israel, mostly new immigrants and living in poor economic and nutritional conditions. In a survey comprising I 59 pregnant women representing all economic groups of Louisiana (Moore et al. 1947), mean haemoglobin values for white women were $12.0 \mathrm{~g} / 100 \mathrm{ml}$ in the second trimester and $1 \mathrm{I} .5 \mathrm{~g}$ in the third. Corresponding values for negro women were 11.3 and $10.9 \mathrm{~g}$. In the Vanderbilt study in Tennessee (Darby, McGanity, Martin, Bridgforth, Densen, Kaser, Ogle, Newbill, Stockell, Ferguson, Touster, McClellan, Williams \& Cannon, 1953) 2129 pregnant women from families of low to moderate income status were studied. Mean haemoglobin values at two stages in the second trimester were 12.0 and $\mathrm{II}_{\mathrm{I}} .9 \mathrm{~g}$ and in the third, II.4 and II.6 g. Similar results were obtained by Macy, Moyer, Kelly, Mack, DiLoreto \& Pratt (1954) in Michigan. These authors state that $52 \%$ of 198 women in the third trimester of pregnancy and visiting public clinics were anaemic (haemoglobin $<10.0 \mathrm{~g} / 100 \mathrm{ml}$ ) as against $4 \%$ out of fifty-three women delivered in private clinics. Our figures are, therefore similar to those found among comparable economic groups in the western world.

The mean value for serum proteins $(6.3 \mathrm{~g} / \mathrm{100} \mathrm{ml})$ was, as expected, lower than the norm for a non-pregnant woman. Similar figures were reported in the above-mentioned studies: in the Louisiana study (Moore et al. 1947), 6.2 $\mathrm{g}$ in the second trimester and 6. $\mathrm{g}$ in the third; in the Vanderbilt survey (Darby et al. 1953), 6.3 $\mathrm{g}$ in both the second and third trimesters; in the study of Macy et al. (1954), 6.I $\mathrm{g}$ in the third trimester in women attending both public and private clinics.

The mean daily calorie intake in our study was $2064 \mathrm{kcal}$. This figure compares well with that (2020) obtained by Darby et al. (1953) and that (204I) found by Moore et al. (1947) for white women but falls below the recent figure (2354) of Thomson (1958) for primigravidae of 'social class C' (semi-skilled and unskilled manual occupations) in Aberdeen. A closer comparison of the results for the last group with the findings in our study shows that on the average the Scottish women consumed more calories, calcium, vitamin A and riboflavin, similar quantities of protein and nicotinic acid, and less ascorbic acid.

It is noteworthy that in spite of enrichment of flour with riboflavin and calcium $7 \%$ of the women consumed less than half the amount of riboflavin and as many as $60 \%$ consumed less than half the amount of calcium recommended by the British Medical Association: Committee on Nutrition (1950). One of the reasons was the 
very low consumption of milk. Higher consumption of milk and milk products should, therefore, be encouraged.

Use of white flour and bread was found to be prevalent. Only very few families ate dark bread. Since flour products play a prominent part in the daily menu (Table 3), any increases in consumption of dark flour would improve the supply of iron and $B$ vitamins. Nutritional education should, therefore, aim at a shifting over from white- to dark-flour products. Finally, in spite of a satisfactory consumption of fruits and vegetables, intake of vitamin $A$ was often not adequate. Guidance in the proper choice of fruits and vegetables could contribute much to an improvement in this respect.

\section{SUMMARY}

I. A clinical and biochemical survey was made of I64 newly immigrant pregnant women of the lower-income groups living in a development area of Israel and a dietary survey was made of 100 of them. One instance of vitamin A deficiency and one suggesting ariboflavinosis were found.

2. The mean haemoglobin value was $11 \cdot 3 \mathrm{~g} / 100 \mathrm{ml}$ with $12 \%$ of the values below 10.0 g. The mean values for serum proteins, albumin and globulin were $6.3,3.9$ and $2.4 \mathrm{~g} / 100 \mathrm{ml}$. The mean daily excretion of riboflavin in morning urine was $24.6 \mu \mathrm{g} / 100 \mathrm{ml}$ or $0.30 \mathrm{mg} / \mathrm{g}$ creatinine.

3. The general level of consumption of nutrients may be appreciated as on the border-line between 'good' and 'fair', but the intake of calcium and vitamin A of $35^{-60} \%$ of the women was definitely inadequate, if judged by the recommendations of the British Medical Association: Committee on Nutrition (1950). The statutary enrichment of flour with soya-bean meal, calcium and riboflavin contributed significantly to the intake of calcium and riboflavin. An increased consumption of milk and milk products, a shifting over from white to dark flour and a proper choice of fruits and vegetables should be encouraged.

The authors are indebted to Dr A. Arnan, District Health Officer, and to the nursing staff of the District Health Office, Be'er-Sheba, for their devoted co-operation. The study was made possible through financial support by the Nutrition Unit of the Ministry of Health of the Government of Israel.

\section{REFERENCES}

Albritton, E. C. (editor) (1954). Standard Values in Nutrition and Metabolism. London and Philadelphia : W. B. Saunders Company.

British Medical Association: Committee on Nutrition (1950). Report of the Committee on Nutrition. London: British Medical Association.

Crosby, W. H., Munn, J. F. \& Furth, F. W. (1954). U.S. Forces med. F. 5, 693.

Darby, W. J., McGanity, W. J., Martin, M. P., Bridgforth, E., Densen, P. M., Kaser, M. M., Ogle, P. J., Newbill, J. A., Stockell, A., Ferguson, M. E., Touster, O., McClellan, G. S., Williams, C. \& Cannon, R. C. (I953). F. Nutr. 5I, 565.

Gornall, A. G., Bardawill, O. J, \& David, M. M. (1949). F. biol. Chem. 177, 75 I.

Halevy, S., Koth, H. \& Guggenheim, K. (1957). Brit. F. Nutr. 11, 409.

Interdepartmental Committee on Nutrition for National Defense (1957). Manual for Nutrition Surveys, pp. 77, 120. Washington, D.C. 
354 K. Guggenheim, Judith Ilan, T. Vago and G. Mundel 1960

Izak, G., Rachmilewitz, M., Stein, Y., Berkovici, B., Sadovsky, A., Aronovitch, Y. \& Grossowicz, N. (1957). Arch. intern. Med. 99, 346.

Joliffe, N., Goodhart, R. S., Archer, M., Lopez, H. \& Diaz, F. G. (1958). F. Nutr. 64, 355.

Kingsley, G. R. (1940). 7. biol. Chem. r33, 731.

Macy, I. G., Moyer, E. Z., Kelly, H. J., Mack, H. C., DiLoreto, P. C. \& Pratt, J. P. (1954). F. Nutr. 52, Suppl.

Moore, M. C., Purdy, M. B., Gibbens, E. J., Hollinger, M. E. \& Goldsmith, G. (1947). F. Amer. diet. Ass. 23, 847 .

Taussky, G. R. (1954). F. biol. Chem. 208, 853 .

Thomson, A. M. (1958). Brit. Y. Nutr. r2, 446.

Watt, B. K. \& Merrill, A. L. (1950). U.S. Dep. Agric. Handb. no. 8.

Weichselbaum, T. E. (1946). Amer. F. clin. Path. 1o, 40.

WHO (1958). Tech. Rep. Wld Hlth Org. no. 182. 